\title{
The Utilizing of Phet Simulation as A Computer- Based Learning Media to Improve The Understanding of College Student's Physics Concepts.
}

\author{
Isabel Coryunitha Panis \\ Department of Physics Education \\ UNWIRA Kupang \\ Kupang, Indonesia \\ isabelcoryunithapanis@yahoo.com
}

\author{
Oktavianus Ama Ki'i \\ Department of Physics Education \\ UNWIRA Kupang \\ Kupang, Indonesia \\ oktaamakii4@gmail.com
}

\begin{abstract}
The computer in physics learning is a course subject on the studi program of physics education of Widya Mandira Kupang university that aimed to prepare college students to use the computer as a physics learning media. The research aims to improve the understanding of physics concepts of college students by utilizing the phET simulation as a computer-based learning media. The study is weak experimental research with The One-Group Pretest-Posttest Design. The treatment in this research is the utilizing of phet Simulation as a computer-based learning media in physics learning. The college students are trained to use PhET simulations and explain the physics concepts present in the simulation. The enhancement of the understanding of physics concepts of college students analyzed using Gain analysis based on the pretest and posttest. The results of the study indicate that the use of Phet simulation as a computer-based learning media can improve the understanding of physics concepts of college students 5th semester of physics department of Catholic University of Widya Mandira Kupang with a high category.
\end{abstract}

Keywords-computer-based learning media, phet simulation, physics concepts, understanding

\section{INTRODUCTION}

At this time, the development of information and communication technology is increasing rapidly. This development presents a new culture in the field of education where the quality and efficiency of education can be improved by utilizing the progress of information technology.

The Computer in physics learning is a course in the study program of Physics education of Widya Mandira Kupang university which aims to prepare the college students in exploiting the technology and communication developments especially in the field of computer to apply in physics learning.

Based on the result of observation during the learning process, the problems found are 1) most of college students are unable to explain the physics concept related to the daily events, (2) The college students are unable to remember the formulas related to the physics concept, (3) The college students unable to deriving the physics equation based on the problems relate to the concept of physics.
Based on the observation, the main problem is the low understanding of physics concepts. The college students tend to memorize the existing physical formulas without learning the physical meaning of that formula. The college students did not attempt to learn how to derive the physics formula from an issue related to the physics concept.

The low of the physics concept understanding will be very influential to the college students in studying the courses of computer in Physics Learning. The college students are required to choose one of computer-based learning media in explaining certain physics concepts. They are only able to display computer-based learning media without being able to explain its concept.

This condition is very apprehensive because these college students will be prospective teachers who are not able to take advantage of technological and information developments. Therefore, there should be an effort to overcome the low understanding of physics concepts of the college student.

Two aspects that stand out in the learning process are methods and media learning. The learning media has the main function as a teaching tool to support the learning method used [1].

By the development of technology, there are many of learning media has created that makes learning is no longer just by telling stories, but can be seen directly in digital, face-toface activities that can be done anywhere. The discussion of abstract and complex problems will become concrete and simple. Therefore, it is necessary to choose one of the learning media to improve the understanding of the physics concepts of the college students.

Education media play an important role in the learning process. The use of educational media can assist lecturers in delivering the lecture material. Teaching methods and learning media are the two main components that determine the success of learning. These components are interrelated and cannot be separated. The selection of one of particular teaching methods will have consequences of the use of the type of appropriate learning media. 
The media word is the plural of the medium word which can be defined as an intermediary or the preface of communication from the sender to the receiver [2].

Gagne says that the media are the different types of components in the student's environment that can stimulate them to learn and the Association of National Education in America defines media within the scope of education as anything that can be manipulated, seen, heard, read or discussed along with the instruments used for that activity [3]. Therefore, the media can be defined as something that can be used to convey messages and can stimulate the thoughts and feelings of students so they motivated to learn.

Media is one of the factors that support the success of the learning process because it can help the process of delivering information from teachers to students or otherwise. Creative use of media can accelerate and improve the efficiency of learning so that learning objectives can be achieved. [3].

The media have a function as a carrier of information from the source (educator) to the recipient (learners) in the learning process. Method is a procedure to assist learners in receiving and processing information in order to achieve learning objectives. The communication will not happen without the media, and the learning process as a communication process also will not be able to take place optimally.

At the interaction activity between learners with the environment, the function of media can be known based on the excess media and the hindrance that may arise in the learning process. Gerlach \& Ely [2] describes the three advantages of media capabilities as follows. First, the fixative ability, meaning it can capture, store, and re-display an object or event. Second, manipulative ability, meaning that media can redisplay objects or events with various changes (manipulation) as needed, such as resized, speed, color, and the presentation can also be repeated. Third, distributive ability, meaning that the media is able to reach a large audience in a single presentation simultaneously, for example; Broadcast TV or radio.

The learning media can be interactive if the learners not only see and hear, but actually interact directly with the learning media. The communication between the media and the learner can go both ways. The communication component in computer-based interactive media is human as user and computer (software).

The interactive information application aims to enable users to get the desired information without having to know everything [3]. Seels \& Glasgow confirm that the interactive learning media are a teaching delivery system that presents recording video material with computer control to the audience (students) who not only hear, watch videos and sound, but students can also provide an active response [4]. The response of the student is used as a determinant of the speed and frequency of presentation.

One of the perceived benefits of interactive multimedia compared to traditional teaching methods is allowing students to work at their own pace. The multimedia has the power to animate, communicate dynamic information more accurately than diagrams and can help students visualize unseen phenomena.

PhET (Physics Education Technology) is a website created by the University of Colorado with the main sponsor of The William and Flora Hewlett Foundation and the National Science Foundation [5]. This site provides free physics, biology, and chemistry learning simulations downloaded for the benefit of classroom teaching or can be used for individual learning purposes [6]. The simulations provided are very interactive and can invite students to learn by exploring directly. This PhET simulation creates an abstract or invisible animation such as: atoms, electrons, photons and magnetic fields, can be observed and interpreted in accordance with scientific studies that have been understood.

PhET Learning Media is an interactive simulation created in the form of a game growing from the scope of knowledge and technological progress that can make a person more sensitive to any changes around him.

PhET simulation can also be used as a substitute for a small number of practicum tools so that the lab work can still be done. With a sufficient number of computers owned by students, students are expected to experiment wherever they are self-taught to more easily understand the teaching materials [7], [8].

The advantage of using virtual labs is that the practice can be done anywhere and anytime, many things that, practically impossible to observe in the lab directly, become possible through animation in the virtual lab whereas the disadvantage is that some motor skills disappear from the practical activity of using this virtual lab. Therefore, the use of a virtual lab as a substitute for a real practicum needs to take into account many things, especially the loss of motor skills required by students at lower levels [9].

How to run a PhET simulation is done very easily. Once installed on the computer, the user only needs to run using a web browser. Although using a web browser, it does not mean this simulation can only be run online. When downloading the PhET simulation installer driver, we can select the installer driver to run offline where the offline installer driver already includes all the simulations that will be used.

This simulation is written in Java and Flash and can be run by using the default web browser as long as Flash and Java plug-ins are installed [10],[11].

PhET Simulation can be downloaded for free on the official PhET website (http://phet.colorado.edu) which provides various simulations in science lessons that can be used for free both online and offline. PhET simulation is very interactive where in this simulation, students can use independently or assisted by the teacher in its use [12].

With the help of phET simulation is expected to increase the understanding of the college student physics concepts. Understanding requires the ability to absorb the meaning or the meaning of a concept. Therefore, there is a need for a relationship between the concept and the meaning of the concept [13]. The relationship between concepts and meanings will result in behavioral changes. 
Bloom [14] stated that there are 7 indicators developed in the level of the cognitive understanding process that is interpreting, exemplifying, classifying, summarizing,inferring, comparing, and explaining. Therefore, the conceptual understanding is a level where students are able to absorb the meaning of a concept both in the form of verbal and written to produce behavioral changes.

\section{METHODS}

This research uses weak experimental method with one group pretest-posttest design. The subjects of this research are college students in 5th semester of physics education UNWIRA Kupang academic year 2016/2017 which amounted to 63 people. In this research, the college students are trained to use PhET simulations and explain the physics concepts present in the simulation.

The concept comprehension test is an essay test with a total of 15 questions that include teaching materials of motion dynamics, elasticity, thermodynamics, Electromagnetics.

The Increased understanding of college student physics concepts is expressed in the percentage of gain scores. The equation of gain score used [14] is

$$
\langle g\rangle=\frac{\left\langle s_{\text {post }}\right\rangle-\left\langle s_{\text {pre }}\right\rangle}{100-\left\langle s_{\text {pre }}\right\rangle}
$$

With $\langle g\rangle$ is the gain factor, $\left\langle s_{p r e}\right\rangle$ is the average score of the initial test, $\left\langle s_{\text {post }}\right\rangle$ is the average score of the final test. The criteria for the increased understanding of physics concepts are classified as follows: high criterion if $\mathrm{g}>0.70$, medium criterion if $0.3<\mathrm{g}<0.7$ and low criterion if $\mathrm{g}<0.3$.

\section{RESULT AND DISCUSSION}

The increased understanding of physics concepts of college student's 5th semesters of physics education UNWIRA Kupang academic year 2016/2017 after being trained using PhET interactive simulation media can be observed in the pre-test and post-test results. The results of pre-test and post-test can be seen in Fig. 1 and Fig. 2.

Based on the Fig. 1, the highest and average score for pretest are 49 and 40, respectively. highest and average score for post-test are 96 and 85, respectively. The pre-test and post test score shows that the increasing of understanding of college student physics concept is very high.

The pre-test and post-test score for the college student with serial number 1-31 can be seen in figure 1 and the serial number 32-63 can be observed in figure 2 .

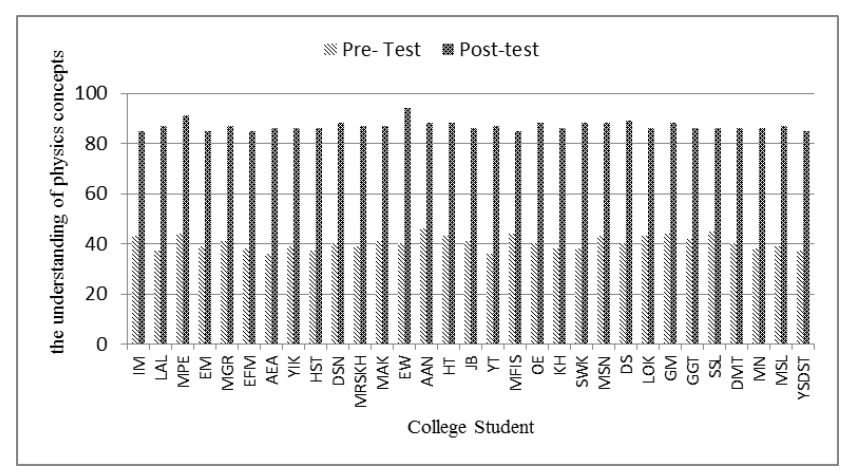

Fig. 1. The increasing of understanding of college student physics concept (Serial Number 1-31)

In the learning process, the lecturer help the college students to install the PhET simulation on their own laptops. Students study one by one physics simulation with guidance from the lecturer. During the training process using PhET simulation, students were asked to study the physics concepts contained in the simulation. College students can also use several simulations to assist them in deriving a physics equation (formula).

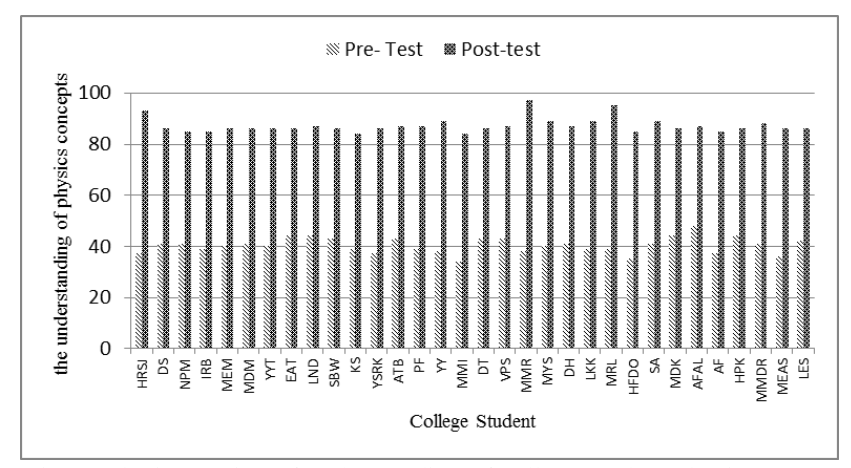

Fig. 2. The increasing of understanding of college student physics concept (Serial Number 32-63)

The results of the Gain analysis of the increasing of understanding of the college students' physics concept can be seen in Table I.

TABLE I. THE RESULTS OF THE GAIN ANALYSIS

\begin{tabular}{|c|c|c|}
\hline Category & Pre-Test & Post-Test \\
\hline Min Score & 33 & 83 \\
\hline Max Score & 49 & 96 \\
\hline Mean & 40 & 85 \\
\hline Gain & & \\
\hline Criteria & & \\
\hline
\end{tabular}

During the training process, each student is asked to demonstrate a simulation and must explain the implicit physics concepts of the simulation and explain how to obtain the related physics equation in it. By doing a demonstration, students will be used to appear in front of the class. Overall, students have been able to demonstrate and explain the 
relationship between simulations that are presented with physics concepts.

The Increased understanding of the college students' physics concept is the influence of PhET simulation as learning media. PhET simulation allows college students to build their own conceptual understanding based on simulations that exist in PhET so that they can more easily understand and remember the physics concept that they learn. It is also mentioned by Tarekegn that Simulations in Student Centered can improve students' skills even if they do not use real instruments [12].

By using a pet simulation, college students can directly prove the truth of a physics equation if applied to daily physics problems. Physics equations that seem abstract can be more easily understood and remembered because it can be directly demonstrated clearly through the simulation. It has also been affirmed by Sahin [15] that the simulations run with the computer can be used to improve the skills of formulating hypotheses, graphical interpretation skills and predicting skills.

Based on the result of Gain analysis that the gain factor is 0,76 with high criterion indicate that the utilizing of pet simulation as learning media can increase the understanding of college student physics concepts of 5th semesters of physics education UNWIRA Kupang academic year 2016/2017. The complexity and intangible of the physics field make it difficult for college students to understand it. The college students are increasingly interested and easy to learn physics using PhET because it provides simple and interactive physics problem simulation. This is also confirmed by Djamarah and Zain [12] and Sanjaya [12] that teachers can use the media to present abstract learning to look more concrete, adds passion and motivation so students will more easily understand the subject matter presented.

Perkins, et al. [12] said that the PhET simulation media is very appropriate for exploration activities in the laboratory for small groups. Finkelstein [12] also said that the pet simulation media have the characteristics of learning activities involving students and interactively, generating the feedback with a constructivist approach.

\section{CONCLUSION}

The utilizing of PhET simulation as learning media can increase the understanding of college student physics concepts of 5th semesters of physics education UNWIRA Kupang academic year 2016/2017. The complexity and intangible of the physics field can be learned and understood by the college students because PhET simulation provides simple and interactive physics problem simulation.

\section{ACKNOWLEDGMENT}

This work was supported by the Widya Mandira Kupang University under grand : 260/WM.H9/SPPKP/2016.

\section{REFERENCES}

[1] Pujiyono; Sudjito, D. N.; Sudarmi, M. Desain Pembelajaran Dengan Menggunakan Media Simulasi PhET (Physics Education and Technology) Pada Materi Medan Listrik. Unnes Physics Education Journal, [S.1.], v. 5, n. 1, sep. 2016. ISSN 2252-6935.

[2] H. Ibrahim, Media Pembelajaran: Arti, Fungsi, Landasan Pengunaan, Klasifikasi,Pemilihan, Karakteristik Oht, Opaque, Filmstrip, Slide, Film, Video, TV, Dan Penulisan Naskah Slide. Bahan sajian program pendidikan akta mengajar III-IV. FIP-IKIP Malang, 1997.

[3] Arda, Saehana, S.,Darsikin. Pengembangan Media Pembelajaran Interaktif Berbasis Komputer untuk Siswa SMP Kelas VIII. E-jurnal Mitra Sains, Vol 3 No 1, Januari 2015 Hlm 69-77.

[4] A. Arsyad, Media Pembelajaran. Pustekkom Diknas \& PT.Raja Grafindo Perkasa. Jakarta, 2005.

[5] Prihatiningtyas, S., Prastowo, T., Jatmiko, B. Imlementasi Simulasi Phet dan Kit Sederhana Untuk Mengajarkan Keterampilan Psikomotor Siswa Pada Pokok Bahasan Alat Optik. Jurnal Pendidikan IPA Indonesia, Vol. 2, No 1, 2013, Hlm. $18-22$.

[6] Sinulingga, P.; Hartanto, T. J.; Santoso, B. Implementasi Pembelajaran Fisika Berbantuan Media Simulasi PhET untuk Meningkatkan Hasil Belajar Siswa Pada Materi Listrik Dinamis. JPPPF - Jurnal Penelitian \& Pengembangan Pendidikan Fisika, Vol. 2, No. 1, p. 57-64, june 2016. ISSN 2461-1433.

[7] A. Perdana, Siswoyo, Sunaryo. Pengembangan Lembar Kerja Siswa Berbasis Discovery Learning Berbantuan PhET Interactive Simulations Pada Materi Hukum Newton. Jurnal Wahana Pendidikan Fisika. ISSN : 2338-1027. Vol.2 No.1 73-79, 2017.

[8] Mursalin. Model Remediasi Miskonsepsi Materi Rangkaian Listrik Dengan Pendekatan Simulasi Phet. Jurnal Pendidikan Fisika Indonesia, Vol. 9, No. 1, 2013, Hlm. 1-7.

[9] Setiadi, R \& Muflika, A.A. Eksplorasi Pemberdayaan Courseware Simulasi PhET Untuk Membangun Ketrampilan Proses Sains Siswa SMA. Jurnal Pengajaran MIPA, Volume 17, Nomor 2, Oktober 2012, hlm. 258-268.

[10] Ekawati, Y., Haris,A., Amin, B.D. Penerapan Media Simulasi Menggunakan PHET (Physics Education And Technology) Terhadap Hasil Belajar Fisika Peserta Didik Kelas X SMA Muhammadiyah Limbung. Jurnal Pendidikan Fisika, Vol.3, Nomor 1, ISSN: 2302-8939, hlm.74-82.

[11] Sumargo, E. \&Yuanita, L., The Application Of Virtual Laboratory Media (Phet) At Reaction Rate Subject Using Direct Instruction Model. Unesa Journal of Chemical Education, ISSN: 2252-9454 Vol.3, No. 1, pp. 119-133, Januari 2014.

[12] Komyadi \& Derlina, Penerapan Media Simulasi PhET untuk Meningkatkan Aktivitas Siswa pada Fase Pengumpulan Data Percobaan dan Mengolah serta Merumuskan Suatu Penjelasan dalam Model Pembelajaran Inquiry Training di SMA Negeri 5 Takengon. Jurnal Pendidikan Fisika, ISSN 2252-732X, Vol. 4, No 1, 2015.

[13] N. Sudjana. Dasar-Dasar Proses Belajar Mengajar. Bandung: Sinar Baru Algensindo, 2013.

[14] Anderson, Lorin W.\& Krathwohl, D.R., A Taksonomi for Learning, Teaching, and Assesing : a Review of Bloom's Taxonomy. New York. Longman Publishing, 2001.

[15] Sahin, Computer Simulations In Science Education : Implications For Distance Education. Turkish Online Journal of Distance EducationTOJDE Volume 7 Number 4 Artcle:12, 2006. 